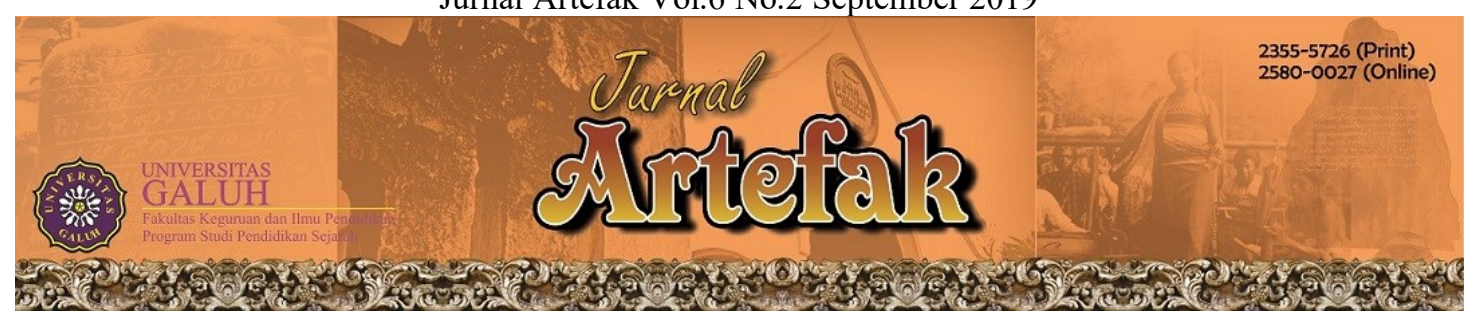

https: //jurnal.unigal.ac.id/index.php/artefak

\title{
TRANSFORMASI KESALIHAN SOSIAL ZAKAT, INFAQ, DAN SHADAQAH MASYARAKAT RANGKASBITUNG PADA TAHUN 1978-2017
}

\author{
Weny Widyawati Bastaman ${ }^{1}$, Siti Sri Suhartini ${ }^{2}$ \\ Sekolah Tinggi Keguruan dan Ilmu Pendidikan Setia Budhi, Indonesia \\ Jl Dr. Budhi Oetomo no. 22L Rangkasbitung, Lebak, Banten \\ Email: wenywb1988@gmail.com \\ Sejarah Artikel: Diterima 19-8-2019, Disetujui 30-8-2019, Dipublikasikan 7-9-2019
}

\begin{abstract}
Abstrak
Penelitian ini bertujuan untuk memperoleh gambaran tentang adat istiadat yang ada pada masyarakat Dusun Kuta, dan bagaimana peran keluarga dalam mensosialisasikan kepada anggota keluarganya. Metode penelitian ini adalah metode kualitatif serta penemuan kuantitatif yang mendukung. Selanjutnya data diinterpretasi, sehingga menghasilkan data deskriptif berupa katakata tertulis dari orang dan perilaku yang dapat diamati. Sedangkan teknik pengumpulan data menggunakan observasi dan wawancara. Hasil penelitian menunjukan dalam proses sosialisasi adat istiadat, keluarga memegang peranan yang amat penting, karena melalaui keluarga inilah anak-anak mengalami proses sosialisasi yang pertama dan mendasari semua proses sosialisasi lebih lanjut. Ibu, bapak mengajari anak-anaknya tentang sikap dan perilaku yang baik menurut adat dan harus dilakukan serta sikap dan perilaku yang tidak boleh dilakukan karena bertentangan dengan adat. Adat istiadat Dusun Kuta yang disosialisasikan itu, antara lain: perilaku dalam hidupan sehari-hari, pekerjaan dalam mencari/mendapatkan nafkah, bentuk dan bahan yang digunakan dalam pembuatan rumah, syarat dan tatacara penentuan kuncen, larangan-larangan dan keharusan-keharusan yang berkaitan dengan keberadaan tempat-tempat yang dianggap keramat.
\end{abstract}

Kata Kunci: Transformasi, Kesalihan Sosial, Zakat, Infaq dan Shadaqah

\begin{abstract}
Zakat, infaq, and sadaqah have been known and carried out by Muslims for a long time. Along with the times in managing zakat, infaq and sadaqah experienced changes and developments. The method used in this study is a historical method consisting of topic selection, heuristics, namely; data collection consisting of primary data sources and secondary data sources, verification, namely; historical criticism or the validity of the source by means of internal criticism and external criticism, interpretation of data namely; interpretation of data that has been verified, and historigraphy, namely; write down the results of the study. The results of this study indicate that in the management of zakat, infaq and sadaqah there are changes and developments. In the history of its development starting from traditional and now there are institutions that manage zakat, infaq and shadaqah in a professional manner, in terms of management, which are initially consumptive but now more productive, and changes in social values from the implementation of zakat, infaq and shadaqah (muzakki) can better know the condition of the mustahik (zakat recipients). Whereas institutionally tend to only carry out obligations.
\end{abstract}

Keyword: Transformation, Social Disability, Zakat, Infaq and Sadaqah

\section{PENDAHULUAN}

Zakat sebagai salah satu kerangka dasar (arkan) dari bangunan Islam, berkedudukan sebagai ibadah yang senantiasa ditampilkan sebagai kembarnya ibadah shalat. Dalam kedudukan itu tentu fungsi utamanya ialah pengembangan kondisi taqarrub ilallah untuk menumbuhkan jiwa pengabdian dan sikap 
loyalitas serta disiplin moral kehidupan sebagai suatu totalitas kehidupan beragama bagi seorang muslim. Di dalamnya terdapat fungsi ganda, yaitu yang menyangkut aspek kemanusiaan dan kebersamaan dalam kehidupan bermasyarakat, yang menyangkut dirinya dan harta miliknya sebagai seorang muslim (Ali Yafie, 1994: 239).

Dengan masyarakat membayar zakat, infak dan shadaqah (ZIS) merupakan bagian dari peningkatan kualitas kesalihan sosial, karena zakat, infak dan shadaqah (ZIS) adalah salah satu ibadah maaliyah (harta benda) yang mengamalkan dan mengaktulisasikan nilainilai ajaran agama Islam dalam segala aspek kehidupan dan merupakan manifestasi ajaran agama dalam kehidupan sosial yang berkenaan dengan kesalihan sosial dalam masyarakat khususnya masyarakat di Rangkasbitung.

Pada tahun 1978 masyarakat Rangkasbitung pada umumnya dalam membayar zakat, infaq dan shadaqah biasanya secara tradisional yaitu menyalurkannya langsung kepada para mustahik (penerima zakat) atau melalui 'amil (perorangan) yaitu Kiyai/Ustadz, atau menyalurkan infaq dan shadaqahnya ke Pondok-Pondok Pesantren. Karena memang pada waktu itu masih belum ada lembaga yang didirikan oleh pemerintah Kabupaten Lebak untuk mengatur pengelolaan dana zakat, infaq dan shadaqah secara lebih optimal.

Adapun lembaga yang berupaya untuk mengelola dana zakat, infaq, dan shadaqah yang terbentuk atas rasa kepedulian sebagian masyarakat yang memandang bahwa dana zakat sebetulnya sangat berpotensial untuk kemakmuran masyarakat Rangkasbitung jika dalam pengelolaannya bisa dikelola dengan lebih baik. Dalam perkembangannya kemudian perhatian dan peranan pemerintah muncul tehadap organisasi pengelola zakat. Ini dibuktikan pemerintah dengan membentuk sebuah lembaga yang bernama Badan Amil Zakat Daerah (BAZDA) Kabupaten Lebak yang berdiri sebelum tahun 1988, berdasarkan keputusan dari Sekwilda (Sekretaris Wilayah Daerah). Dan pada tahun 1988 kepengurusan BAZDA Lebak masih dikelola oleh para Ulama, melalui musyawarah daerah dengan ditunjuk oleh KESRA (Kesejahteraan Rakyat), dalam pendistribusian dana zakat, infaq dan shadaqah ini masih bersifat konsumtif (Sumber : BAZNAS, 14 Agustus 2017).

Pengembangan dan pengelolaan zakat menjadi perhatian serius dari Pemerintah (eksekutif dan legislatif) yang diaplikasikan antara lain dalam bentuk Penetapan Peraturan Daerah Nomor 11 tahun 2005 tentang Pengelolaan Zakat. Perda ini merupakan penegasan terhadap penghimpunan dan penyaluran zakat yang dilakukan oleh 'amilin (pengurus zakat) harus secara amanah dan bekerja secara profesional. 'Amil adalah orang-orang yang ditugaskan (diutus oleh Imam/Pemerintah) untuk mengambil, menuliskan, menghitung dan mencatat zakat yang diambilnya dari para muzakki (pemberi zakat) untuk kemudian diberikan kepada yang berhak menerimanya (para mustahik). Oleh karenanya, di Lebak, baik eksekutif maupun legislatif sepakat dengan para ulama bahwa peran zakat sangat berpengaruh secara signifikan terhadap pembangunan daerah jika diatur dan dikelola dengan baik dan profesional oleh pengurus BAZDA Lebak.

Dalam rangka meningkatkan dayaguna dan hasil guna pengelolaan, zakat, infaq dan shadaqah harus dikelola secara kelembagaan dan profesional sesuai dengan syariat Islam yang dilandasi dengan prinsip amanah, bermanfaat, keadilan, kepastian hukum, terintegrasi, akuntabilitas sehingga dapat meningkatkan pelayanan dan pengelolaan zakat. Maka dari itu Badan Amil Zakat Daerah (BAZDA) kabupaten Lebak mengalami perubahan nama menjadi Badan Amil Zakat Nasional (BAZNAS). Hal ini didasari hukum pembentukan BAZNAS berdasarkan : (1) Undang-undang Republik Indonesia Nomor 23 Tahun 2011 tentang Pengelolaan Zakat. (2) Pengaturan Pemerintah Nomor 14 Tahun 2014 tentang Pelaksanaan Pengelolaan Zakat. (3) Pengaturan Badan Amil Zakat Nasional Nomor 01 Tahun 2014 tentang Pengangkatan dan Pemberhentian Pimpinan BAZNAS. (4) Pengaturan Badan Amil Zakat Nasional Nomor 03 Tahun 2014 tentang Organisasi dan Tata Kerja BAZNAS (Sumber : BAZNAS, 14 Agustus 2017).

Potensi zakat, infaq, dan shadaqah di kabupaten Lebak khususnya di Rangkasbitung selama ini memang belum dikembangkan secara optimal, dan belum ditata serta dikelola secara profesional. Dalam hubungan ini, setiap pengungkapan persoalan zakat, infaq dan 
shadaqah merupakan suatu upaya yang berharga untuk menggugah perhatian semua pihak ke arah aktualisasi dan implementasi nilai-nilai agama Islam yang berorientasi pada kehidupan nyata, serta mengangkat ke permukaan norma-norma Islam yang mampu memberi jawaban atas kenyataan hidup kita dalam bermasyarakat dan berbangsa, serta mampu mewujudkan masyarakat yang salih baik secara individual maupun secara sosial.

Namun, ajaran-ajaran yang terkandung dalam pelaksanaan zakat, infaq, dan shadaqah tersebut masih jauh dari yang diharapkan, sebab tidak sinkronnya antara pengetahuan dan pengamalan mengenai zakat, infaq dan shadaqah, hal ini disebabkan oleh beberapa faktor dintaranya minimnya pengetahuan dan kesadaran masyarakat akan kewajiban mengeluarkan zakat, infaq, dan shadaqah sehingga masih banyak prilaku masyarakat yang tidak peduli dengan nilai-nilai Islami, rasa kemanusiaan dan solidaritas sosial yang rendah, tumbuhnya sifat kikir, rakus, dan matrealistis yang tinggi an berkolerasi pada partisipasi masarakat dalam membayar zakat, infaq dan shadaqah yang dilakukan baik melalui 'amil (perorangan) yang dikelola secara tradisional dan disalurkan langsung kepada para mustahik (penerima zakat) yang bersifat konsumtif, maupun pembayaran zakat, infaq dan shadaqah melalui institusi lembaga pemerintah seperti Dewan Kemakmuran Masjid (DKM) dan Badan Amil Zakat Nasional (BAZNAS) yang mengalami perubahan cukup signifikan. Hal ini dikarenakan pemerintah dengan undangundangnya menghimbau bagi orang-orang yang sudah sesuai syarat-syarat hukum Islam untuk membayarkan zakatnya.

\section{METODE PENELITIAN}

Metode yang digunakan dalam penelitian ini adalah metode historis. menurut Louis Gottchalk (Abdurrahman, 1999: 44) menjelaskan bahwa "metode sejarah memiliki pengertian sebagai suatu proses menguji dan menganalisis kesaksian sejarah guna menemukan data yang otentik dan dapat dipercaya, serta usaha sintesis atas data semacam itu menjadi kisah sejarah yang dapat dipercaya". Menurut Kuntowijoyo (2003: 89), mengemukakan bahwa langkah-langkah dalam metode sejarah terdiri atas lima tahapan, yaitu :

\section{Pemilihan Topik}

Menurut Kartodirdjo (1992: 50) yang mengartikan sejarah sosial secara luas, menganggap "setiap gejala sejarah yang menanifestasikan kehidupan sosial suatu komunitas atau kelompok, dapat disebut sejarah sosial". Oleh karena itu, dalam peneliti mencoba untuk mengangkat tema mengenai sejarah sosial di Rangkasbitung Kabupaten Lebak-Banten. Kajian tentang kegiatan masyarakat Rangkasbitung dalam pembayaran, penghimpunan, pengelolaan dan penyaluran zakat, infaq dan shadaqah maka yang akan dikaji adalah "Transformasi Kesalihan Sosial Zakat, Infaq, dan Shadaqah Masyarakat Rangkasbitung pada Tahun 19782017 ".

\section{Heuristik}

Sumber data dalam penelitian adalah subjek dari mana data yang diperoleh (Arikunto, 2010: 114). Secara umum sumber sejarah terdiri dari tiga jenis yaitu sumber lisan berupa pemaparan atau cerita mengenai objek yang sedang dikaji; sumber tulisan berupa catatan-catatan penting yang terkait dengan objek kajian; dan sumber benda berupa peninggalan berbentuk barang yang berhubungan dengan objek kajian.

Dalam penelitian ini, sumber yang digunakan yaitu sumber lisan dan tulisan. Sumber lisan diperoleh dari hasil wawancara dengan narasumber yang dianggap mengetahui tentang objek kajian yaitu sejarah perkembangan pengelolaan dan pendayagunaan zakat, infaq dan shadaqah di Rangkasbitung. Adapun yang menjadi narasumber tersebut diantaranya: Pengurus BAZNAS Kecamatan Rangkasbitung, dimana merupakan pihak yang berhubungan langsung dalam upaya mengoptimalkan pengelolaan pendayagunaan harta ZIS (zakat, infaq, dan shadaqah) sebagai sarana yang mengatur masalah pengelolaan zakat, Infaq, dan shadaqah secara efektif, profesional dan modern. Selain itu juga dilakukan wawancara terhadap narasumber lainnya yaitu Pengurus DKM Al-A'raaf.

Sumber tulisan yang digunakan dalam penelitian ini adalah catatan-catatan mengenai zakat, infaq, dan shadaqah baik berupa buku maupun karya ilmiah yang diperoleh dari internet. Untuk melengkapi sumber data, 
digunakan juga dokumentasi penelitian berupa foto-foto yang berkaitan dengan objek kajian.

\section{Verifikasi}

Langkah berikutnya adalah melakukan kritik keabsahan data atau menganalisi data yang telah diperoleh. Kritik dalam penelitian sejarah terbagi menjadi dua, yaitu kritik internal dan kritik eksternal. Adapun yang dimaksud dengan kritik internal adalah mempertanyakan kebenaran dari pernyataanpernyataan narasumber. Cara yang dilakukan adalah dengan membandingkan informasi yang didapatkan dari tiap narasumber, apakah saling bertentangan atau memiliki kesamaan.

Selain melakukan kritik internal, dilakukan juga kritik eksternal yaitu mempertanyakan keterkaitan dari narasumber terhadap objek kajian, apakah narasumber yang bersangkutan memang mengetahui tentang objek kajian atau tidak. Dalam hal ini, peneliti sejarah harus mampu memilah tokohtokoh yang akan dijadikan narasumber. Pada pelaksanaannya, sebelum melakukan wawancara, peneliti sudah mendapatkan data awal mengenai tokoh-tokoh yang akan dijadikan narasumber. Sebagai sumber utama, yaitu pengurus BAZNAS Kecamatan Rangkasbitung, pengurus DKM Al-A'raaf, tokoh masyarakat Rangkasbitung yang menghimpun ZIS ('amil) secara tradisional atau perorangan, karena mereka merupakan pelaku kegiatan sekaligus tokoh yang berperan dalam pengelolaan dan pendayagunaan harta zakat, infaq dan shadaqah di Rangkasbitung. Selain itu peneliti juga menjadikan masyarakat Rangkasbitung yang membayar zakat (muzakki), infaq dan shadaqah sebagai narasumber. Dengan demikian, integritas mereka ketika mengeluarkan penjelasan tidak akan menyimpang dari tujuan penelitian yang diharapkan.

\section{Interpretasi Data}

Pada dasarnya interpretasi merupakan pendapat pribadi dari peneliti berupa pemberian makna atau memberikan penafsiran tentang suatu kejadian di masa lampau berdasarkan fakta-fakta yan diperoleh selama penelitian berlangsung. Pada penelitian ini, diperoleh banyak informasi mengenai sejarah perkembangan pengelolaan dan pendayagunaan zakat, infaq dan shadaqah di Rangkasbitung pada tahun 1978-2017. Dari informasi-informasi tersebut, peneliti berupaya untuk memberikan pandangannya didasarkan pada kebutuhan penelitian. salah satu bagian dari interpretasi yang dilakukan adalah mengenai sejarah perkembangan pengelolaan dan pendayagunaan zakat, infaq dan shadaqah di Rangkasbitung pada tahun 1978-2017 dan hubungannya dengan kesalihan sosial masyarakat Rangkasbitung pada tahun 1978-2017.

\section{Historiografi (Penulisan)}

Langkah terakhir yang dilakukan dari seluruh proses penelitian adalah penyusunan laporan atau menuliskan hasil penelitian yang telah dilakukan. Informasi yang diperoleh selama pencarian sumber, dilakukan kritik dan interpretasi terhadap data yang diperoleh, kemudian dideskripsikan menjadi satu tulisan yang menyeluruh mengenai transformasi kesalihan sosial zakat, infaq dan shadaqah masyarakat Rangkasbitung pada tahun 19782017.

\section{HASIL PENELITIAN DAN PEMBAHASAN}

\section{Masa Tradisional: 'Amil (Perorangan)}

Pada tahun 1978 masyarakat Rangkasbitung pada umumnya dalam membayar zakat, infaq dan shadaqah biasanya menyalurkannya langsung kepada para mustahik (penerima zakat) atau melalui 'amil (perorangan) yaitu Kiyai/Ustadz, atau menyalurkan infaq dan shadaqahnya ke Pondok-Pondok Pesantren. Karena memang pada waktu itu masih belum ada lembaga yang didirikan oleh pemerintah kabupaten Lebak untuk mengatur pengelolaan dana zakat, infaq dan shadaqah secara lebih optimal. Hal ini berdasarkan keterangan yang peneliti dapat dari beberapa narasumber yang di wawancarai.

Selain itu menurut penuturan Bapak H. Imong selaku muzakki (pemberi zakat) yang berusia 70 tahun (wawancara, 06 Agustus 2017) beliau menceritakan bagaimana tata cara penyaluran zakat, infaq, dan shadaqah yang beliau lakukan, yaitu biasanya dalam pembayaran zakat, baik itu zakat fitrah maupun zakat maal termasuk infaq dan shadaqahnya, beliau lebih mempercayakan kepada para tokoh ulama yang ada disekitar kampungnya. Hal ini cukup beralasan selain belum adanya lembaga resmi pengelola zakat, infaq dan shadaqah pada saat itu, tersebab 
masih banyak para mustahik (penerima zakat) yang berada dilingkungan beliau, maka dari itu dalam penyalurannya dilakukan secara langsung kepada para mustahik (penerima zakat) dengan meminta tokoh agama kampung (kiyai/ustad) untuk membacakan doa bersama agar harta yang dikeluarkan zakatnya bisa lebih berkah bagi si muzakki (pemberi zakat) khususnya, dan bisa memberikan kemanfaatan serta kebahagiaan untuk para penerima zakat mustahik (penerima zakat) yang memang membutuhkan.

\section{Masa Kelembagaan:}

Dewasa ini keberadaan lembaga pengelola zakat merupakan sebuah solusi dalam metode penyaluran zakat untuk tujuan pemberdayaan dana zakat, infaq dan shadaqah (ZIS). Dalam al-Qur'an dan Hadist telah dijelaskan mengenai adanya petugas zakat (amil) yang mengambil zakat dari muzakki (pemberi zakat) kemudian disalurkan kepada para mustahik (penerima zakat). Oleh karena itu, keberadaan lembaga amil zakat sangat diperlukan dalam penghimpunan dan pengelolaan dana zakat. Pelaksanaan zakat selain didasarkan pada surat At-Taubah ayat 103, didasarkan juga dalam surat At-Taubah ayat 60 mengenai golongan-golongan yang berhak menerima zakat.

Masjid (Agung Al-A'raaf menjadi sarana peribadatan baik bersifat ritual maupun sosial. Dalam sejarah mencatat bahwa awal berdirinya Masjid kota Rangaksbitung pada tahun 1932, sejak pemerintahan kolonial Belanda. Seiring berjalannya waktu Masjid kota Rangkasbitung ini dinamakan Masjid Agung Al-A'raaf pada tahun 1988 dan sudah mengalami perubahan beberapa kali

\section{Masa Modern di Era Teknologi:}

Pada tahun 1999 turunlah Surat

Keputusan Bupati yang berdasarkan Undangundang No. 38 Tahun 1999 tentang Pengelolaan Zakat. Dimana isi UndangUndang tersebut, tentang pengelolaan zakat berasaskan iman dan takwa, keterbukaan, dan kepastian hukum sesuai dengan Pancasila dan Undang-Undang Dasar 1945 (pasal 4). Sedangkan tujuan pengelolaan zakat adalah meningkatkan pelayanan bagi masyarakat dalam menunaikan zakat sesuai dengan tuntutan agama, meningkatnya fungsi dan peranan pranata keagamaan dalam upaya mewujudkan kesejahteraan masyarakat dan keadilan sosial, meningkatkan hasil guna dan daya guna zakat (pasal 5). Sehingga hal ini dirasa pemerintah perlu adanya pengaturan mekanisme pengumpulan dan pendistibusian atau pendayagunaan dana zakat, infaq dan shadaqah di Rangkasbitung, kabupaten Lebak. Yang pada saat itu, pengelolaan BAZDA Lebak diketuai oleh KH. M. Mas'ud yang menjabat selama dua periode. Periode pertama yaitu tahun 1988-2002, dan periode kedua yaitu tahun 2002-2006. Pemasukan awal periode tersebut dengan memperoleh kas masuk tiap tahun sekitar Rp. 300-400 juta. Ini menunjukan bahwa adanya peningkatan dalam penghimpunan dana zakat, infaq dan shadaqah (Sumber : profil BAZNAS, 14 Agustus 2017).

Berdasarkan pada Keputusan Bupati Lebak Nomor.400/Kep.54/Sos/2007 tentang Pembentukan Pengurus Badan Amil Zakat (BAZ) Kabupaten Lebak 2007/2017, Dewan Pertimbangan dipimpin oleh Ketua MUII Lebak. Sedangkan Ketua Komisi Pengawas adalah H. Mulyadi Jaya Baya. SK Bupati juga menetapkan Badan Pelaksana yang diketuai oleh Ir. H. Amir Hamzah, M.Si. dilihat dari personalianya, komposisi Badan Pelaksana BAZDA Lebak mungkin sedikit berbeda coraknya dengan beberapa BAZ di kabupaten lain yang menempatkan orang-orang yang sudah pensiun sebagai personalia. Asumsinya mungkin mereka akan lebih banyak waktu yang bisa diluangkan untuk BAZDA. Namun, di BAZDA Lebak semua pengurus di Badan Pelaksana adalah fase produktif yang harus totalitas bekerja dan mengutamakan produktifitas karya. Sedangkan untuk pemenuhan kerja keseharian kesekretariatan, BAZDA dikelola oleh tenaga professional yang dibayar untuk itu. Dalam waktu dekat itu, BAZDA juga sedang mengupayakan untuk meminta Pemerintah Kabupaten agar menempatan beberapa PNS sebagai tenaga bantuan di BAZDA (Sumber: profil BAZNAS, 14 Agustus 2017).

Pengembangan dan pengelolaan zakat menjadi perhatian serius dari Pemerintah (eksekutif dan legislatif) yang diaplikasikan antara lain dalam bentuk penetapan peraturan Daerah Nomor 11 tahun 2005 tentang Pengelolaan Zakat. Perda ini merupakan penegasan terhadap penghimpunan dan penyaluran zakat yang dilakukan oleh amilin 
harus secara amanah dan bekerja secara profesional. 'Amil adalah orang-orang yang ditugaskan (diutus oleh Imam/Pemerintah) untuk mengambil, menuliskan, menghitung dan mencatat zakat yang diambilnya dari para Muzakki (pemberi zakat) untuk kemudian diberikan kepada yang berhak menerimanya (para Mustahik). Oleh karenanya, di Lebak, baik eksekutif maupun legislatif sepakat dengan para ulama bahwa peran zakat sangat berpengaruh secara signifikan terhadap pembangunan daerah jika diatur dan dikelola dengan baik dan profesional oleh pengurus BAZDA Lebak (Wawancara dengan H. Eri Rachmat (62 Tahun) tanggal 14 Agustus 2017).

Transformasi Pengelolaan Zakat, Infaq, dan Shadaqah Masyarakat Rangkasbitung pada Tahun 1978-2017

Pengelolaan Dana ZIS yang ada pada masa Tradisional

\section{Proses Penghimpunan}

Dalam pola penghimpunan zakat, infaq dan shadaqah secara tradisional yaitu berdasarkan pada kepercayaan masyarakat terhadap 'amil atau kiyai yang di kehendaki, dalam membayarkan zakat, infaq dan shadaqahnya. Para ulama/Kiyai hanya memberikan pengetahuan, arahan dan bimbingan mengenai ilmu tentang zakat, infaq dan shadaqah, misalnya bagimana tata cara perhitungannya, apa saja jenis harta kekayaan yang menjadi objek zakat, berapa jumlah nishab atau jumlah minimal yang menyebabkan harta terkena kewajiban untuk dizakatkan, bagaimana dengan ketentuan waktunya, hukumnya seperti apa, ketentuanketentuan sanksi jika tidak mengelurkan zakat, sampai kriteria orang yang wajib mengeluarkan zakat (muzakki), kriteria orang yang berhak menerima zakat (mustahik) dan sebagainya yang berkaitan dengan ilmu zakat, infaq dan shadaqah (Wawancara dengan KH. Dace Sofyan, 09 Agustus 2017).

\section{Proses Penyaluran}

Adapun dalam penyalurannya berdasarkan hasil wawancara dengan Ust Ajat (wawancara, 06 Agustus 2017), "Penyaluran dana zakat, infaq dan shadaqah yang dilakukan masyarakat Rangkasbitung secara tradisional, selain para Muzakki (pemberi zakat) langsung menyerahkan dan membagikan harta zakatnya kepada para
Mustahiq. Ada juga sebagian masyarakat yang membayarkan zakat, infaq dan shadaqahnya kepada 'amil perorangan yaitu kepada tokoh para ulama yang berada disekitar lingkungannya seperti disalurkan melalui ustad/kiyai-kiyai yang memiliki pondok pesantren. Hal ini disebabkan bentuk kepercayaan masyarakat terhadap para tokoh ulama, yang dianggap religius dan paham akan ajaran agama Islam sehingga dengan pengetahuan akan keilmuan agama Islam yang dimilikinya dirasa akan mempunyai sifat yang amanah, sehingga zakat yang akan disalurkannya akan sesuai dengan yang didasarkan dalam Al-Qur'an.

Upaya 'Amil dalam Membangun Spirit Zakat, Infaq dan Shadaqah Masyarakat Rangkasbitung.

Beberapa upaya yang dapat dilakukan oleh para 'Amil agar masyarakat mau atau semangat untuk berzakat, infaq dan shadaqah yaitu,

"Dengan memberikan contoh terlebih dahulu oleh para 'amilin dalam prilaku, karena jauh lebih bagus memberikan contoh dengan prilaku dibandingkan dengan lisan. Adapun dengan lisan yaitu para amilin bisa membahas mengenai ilmu zakat, infaq dan shadaqah dalam pengajian-pengajian, di berikan pemahaman tentang zakat, infaq dan shadaqah" (Wawancara dengan Ust. Ajat, 06 Agustus 2017).

\section{Pengelolaan Dana ZIS yang ada pada DKM Al-A'raaf Kota Rangkasbitung}

Dewan Kemakmuran Masjid Al-A'raaf kota Rangkasbitung dapat berfungsi sebagai wadah pelayanan pengelolaan zakat, infaq dan shadaqah, karena di tunjang dengan adanya kepengurusan DKM yang mampu mengelola manajemen Masjid secara professional. Adapun DKM Al-A'raaf mulai ikut serta dalam pengelolaan dana zakat, infaq dan shadaqah sudah dilakukan sejak lama.

\section{Proses Penghimpunan}

Pola penghimpunan dana zakat, infaq dan shadaqah yang dilakukan oleh para pengurus DKM Al-A'raaf tidak jauh berbeda dengan pola penghimpunan zakat, infaq dan shadaqah secara tradisional, yaitu dengan sosialisasi kepada masyarakat sekitar mengenai hukum dalam membayar zakat, infaq dan shadaqah bagi umat muslim, 
bagaimana keutamaan dari pelaksanaan zakat, infaq dan shadaqah bagi mereka baik selaku muzakki (pemberi zakat) maupun mustahik (penerima zakat). Yang membedakannya dari pengelolaan secara tradisional, dalam pola penghimpunan dana zakat, infaq dan shadaqah ini lebih terstruktur. di DKM Al-A'raaf.

\section{Proses Pendayagunaan}

Dengan semakin luasnya objek zakat dengan jenis usaha yang sangat variatif baik itu di bidang pertanian, perindustrian, peternakan maupun profesi, hal ini memberikan peluang yang besar untuk penggalangan dana dari sektor zakat, infaq dan shadaqah. Akan tetapi kesuksesan dalam penggalangan dana saja tidak akan mencapai sasaran, jika pendistribusian dana zakat tidak dikelola secara professional. Kenyataan di lapangan, pendistribusian zakat, infaq dan shadaqah merupakan salah satu faktor yang dijadikan tolak ukur bagi masyarakat muslim Rangkasbitung untuk memilih lembaga yang dipercaya dalam pengelolaan zakat, infaq dan shadaqah, kekhawatiran masyarakat bahwa dana yang ada, akan sampai atau tidak kepada yang berhak, ini sangat mempengaruhi pada kinerja lembaga itu sendiri, sebab kepercayaan masyarakat merupakan hal utama dalam proses pendayagunaan dana zakat, infaq dan shadaqah ini .

\section{Proses Penyaluran}

Dana zakat, infaq dan shadaqah yang sudah terhimpun ini dalam pola penyalurannya berbeda antara zakat, infaq dan shadaqah, terlebih zakat fitrah, hal ini dikarenakan ketentuan hukum syariat dalam pola penyaluran zakat fitrah yang memang sudah di atur dalam Al-Qur'an, yaitu :

\section{Pengelolaan Dana ZIS yang ada pada BAZNAS Kabupaten Lebak.}

Dengan lahirnya Undang-undang No. 38 tahun 1999 tentang pengelolaan zakat, maka tiap pengelola zakat, infaq dan shadaqah sperti Badan Amil Zakat (BAZ) dan Lembaga Amil Zakat (LAZ) agar benar-benar amanah, jujur, terampil professional dan bertanggung jawab dalam melaksanakan tugas pengabdian sebagai pengurus (amil) pada BAZ maupun LAZ. Oleh karenanya diharapkan para pengelola zakat baik BAZNAS maupun LAZ dari tingkat nasional sampai UPZ (Unit Pengelolaan Zakat) tingkat kecamatan harus mampu merubah kehidupan umat yang tadinya sebagai penerima zakat (Mustahik) menjadi pemberi zakat (Muzakki).

Selain itu, disamping meningkatkan kualitas peran muzakki (pemberi zakat) terhadap mustahik (penerima zakat), para amilin (pengurus zakat) juga harus mampu memberikan pemahaman nilai-nilai sosial yang terdapat dalam konsep dasar dari pembayaran zakat, infak dan shadaqah sehingga masyarakat diharapkan mampu mengamalkan, dan mengaktulisasikan nilainilai ajaran agama Islam dalam segala aspek kehidupan merupakan manisfestasi ajaran agama dalam kehidupan sosial yang berkenaan dengan kesalihan sosial .

\section{Proses Penghimpunan}

Dalam penggalangan dana zakat, infaq dan shadaqah yang dilakukan oleh BAZNAS Kabupaten Lebak, yaitu dengan melaksanakan program kerja yang sudah tersusun diantaranya Program Promosi dan Sosialisasi Zakat, Infaq dan Shadaqah, dengan mengadakan kegiatan-kegiatan.

Sumber zakat yang terhimpun pada BAZNAS sebagai sumber dana umat Islam yang diharapkan dapat mewujudkan kesejahteraan, keadilan sosial serta meningkatkan kualitas hidup baik untuk para Mustahik selaku penerima zakat, maupun peningkatan kualitas hidup para Muzakki (pemberi zakat) yang dengan ikhlas untuk mengeluarkan sebagian kecil harta yang dimilikinya. Sumber dana zakat, infaq dan shadaqah BAZNAS berasal dari masyarakat baik individu, kelompok, organisasi, perusahaan atau pemerintah yang akan digunakan untuk membiyai program dan kegiatan operasional lembaga dalam rangka mencapai tujuan.

\section{Proses Penyaluran}

Selain itu penyaluran dan zakat, infaq dan shadaqah pada BAZNAS Kab Lebak dilakukan dengan membagi penggunaan dana menjadi 3 bagian, hal ini bersumber dari profil BAZNAS, 2017 yaitu :

a. Penggunaan Berdasarkan Program

BAZNAS Kabupaten Lebak mempunyai program unggulan yaitu :

1) Menyalurkan santunan serta pembinaan bantuan kepada para Mustahik.

2) Memberdayakan ekonomi umat melalui pinjaman dana bergulir 
untuk pengusaha/ pedagang kecil dan pondok pesantren.

3) Memberikan bantuan pendidikan melalui beasiswa santri salafi, beasiswa pelajar/ mahasiswa dan beasiswa calon hafidz/hafidzoh.

4) Peningkatan kualitas hidup dhu'afa (PKHD) melalui pengobatan gratis dan khitanan masal bagi kelompok golongan ekonomi lemah.

5) Memberikan bantuan kepada khotib/da'i

6) Pembangunan klinik Baznas Lebak.

7) Memberikan bantuan dan pelayanan pada Muallaf dan Fisabilillah

8) Memberikan santunan dan pembinaan bagi fuqara' dan masakin pada saat tertentu termasuk gepeng dan anjal bekerjasama dengan seksi pemberdayaan Baznas.

9) Mengupayakan tersedianya lahan tanah untuk pengembangan jangka panjang Baznas Lebak.

10) Pembangunan masjid monumental (model) Baznas Lebak di setiap kecamatan (untuk 1 atau 2 Masjid dalam 1 tahun).

11) Penyediaan ambulance BAZNAS Lebak untuk kaum dhuafa dan masyarakat yang membutuhkannya.

12) Bedah rumah (model) Baznas Lebak untuk kaum dhuafa.

13) Membantu biaya kesehatan bagi orang miskin.

14) Pembangunan Air bersih.

b. Penggunaan Berdasarkan Permohonan Dana ini diberikan bagi para pemohon bantuan yang mengajukan proposal kepada BAZNAS kabupaten Lebak untuk para mustahik dari majlis ta'lim, pondok-pondok pesantren. Bidang Keuangan beserta Bidang Pendayagunaan melakukan verifikasi terhadap proposal permohonan yang diajukan apakah layak atau tidak. Baru kemudian (BAZNAS) memberikan dananya untuk disalurkan. (Sumber: profil BAZNAS, 14 Agustus 2017). c. Penggunaan untuk Kegiatan Operasional Dana ini diadakan untuk mengantisipasi penggunaan dana zakat (khususnya bagi amil).

Transformasi Nilai-Nilai Sosial Zakat, Infaq, dan Shadaqah Masyarakat Rangkasbitung pada Tahun 1978-2017

Nilai sosial zakat, infaq, dan shadaqah pada hakikatnya yaitu nilai-nilai yang dianggap baik oleh masyarakat yang terkandung dalam pelaksanaan zakat, infaq dan shadaqah yang menyangkut kesejahteraan dan keberkahan dalam hidup bersama secara harmonis. Zakat, infaq dan shadaqah merupakan ibadah yang memiliki dua sisi. Pada satu sisi Zakat, infaq dan shadaqah merupakan ibadah yang berfungsi sebagai penyucian terhadap harta dan diri pemiliknya. Pada sisi lain Zakat, infaq dan shadaqah mengandung makna sosial yang tinggi.

Asas dan landasan hukum dalam pengelolaan zakat, infaq dan shadaqah yaitu berasaskan pada Al-Qur'an dan Al-Hadist. Beberapa penjelasan mengenai zakat, infaq dan shadaqah pada Al-Qur'an dan Al-hadis

\section{Nilai-Nilai Sosial ZIS Berdasarkan Tujuan dan Fungsinya}

Adapun nilai sosial zakat, infaq dan shadaqah jika kita tinjau dari tujuan dan fungsi pelaksanaan zakat, infaq dan shadaqah yaitu pada dasarnya sama, nilai sosial yang ingin dicapai baik melalui amil perorangan, melalui DKM atau BAZNAS, yakni sama-sama bertujuan untuk membersihkan harta yang dimiliki, menyucikan jiwa, dan dapat membantu meringankan beban orang yang membutuhkan. Selain itu zakat juga bertujuan untuk menyucikan hati para muzakki (pemberi zakat) atau pihak yang mengeluarkan zakat dari sifat kikir, bakhil, dan pelit yang merupakan sifat dasar manusia.

\section{Nilai-Nilai Sosial ZIS Berdasarkan Hikmahnya}

Hikmah daripada zakat bagi pribadi para Muzakki (pemberi zakat) atau pihak yang mengeluarkan zakat diantaranya adalah zakat mampu mendidik jiwa agar menjadi suka berinfaq, dan memberi, berakhlak dengan akhlak Allah, zakat juga merupakan manisfestasi rasa syukur atas nikmat Allah, zakat bisa mengobati hati yang terlalu cinta 
akan dunia, mengembangkan kekayaan batin, menarik simpati untuk para Mustahik, juga mengembangkan harta yang dimiliki (Syahruddin El Fikri, 2014: 80).

Selain itu nilai sosial yang terkandung dalam pelaksanaan zakat, infaq dan shadaqah yaitu meminimalisir kriminalitas dalam masyarakat, seperti : pencurian, perampokan, PSK, dsb. Mampu membersihkan jiwa yang melakukan zakat, infaq dan shadaqah dari penyakit rakus, serakah, kikir dan bakhil yang akan menghancurkan dirinya, baik di dunia maupun di akhirat kelak. Menjadi penyebab turunnya rahmat Allah swt. Dapat menghapus kesalahan dan dosa, pembuktian kejujuran iman orang yang membayarkannya. Dan bentuk mensyukuri nikmat harta yang Allah swt berikan.

Hikmah daripada penyaluran zakat, infaq dan shadaqah kepada BAZNAS yaitu dana zakat, infaq dan shadaqah yang di himpun bisa tersalurkan tepat sasaran, sedangkan ketika membayar zakat, infaq dan shadaqah secara konvensional missal ke guru ngaji, ke kiyai, atau ke imam-imam masjid, dana zakat tersebut bila tidak di salurkan kembali kepada para mustahik maka hanya akan tertuju pada orang tersebut, sehingga dalam penyaluran zakatnya (secara tradisional) tidak merata atau bisa dikatakan tidak tepat sasaran. Dengan adanya lembaga BAZNAS ini berusaha untuk mendistribusikan dana ZIS yang sudah terhimpun untuk di salurkan kepada para mustahik dengan meminta data orang-orang yang perlu di bantu atau yang memenuhi syarat untuk menerima zakat berdasarkan hasil pendataan UPZ (unit penghimpunan zakat) dari tingkat kecamatan/kelurahan sehingga dana zakat tersebut di salurkan tepat sasaran. Adapun keburukannya, dalam pendistribusian dana ZIS yang di salurkan kepada UPZ-UPZ di setiap kecamatan, desa/kelurahan, yang menjadi para mustahiknya sebagian besar keluarga atau kerabat pengurus penyaluran dana ZIS di tingkat kecamatan, desa/kelurahan tersebut.

\section{Nilai Kesalihan Sosial pada Zakat, Infaq dan Shadaqah}

Adapun definisi kesalihan sosial yang dikemukakan oleh Abdul Jamil Wahab (2015) dalam penelitiannya yang berjudul "Indeks Kesalehan Sosial Masyarakat Indonesia"
[Online] mengatakan bahwa "Kesalihan sosial sejatinya adalah merupakan manifestasi dari kesalihan individual, tanpa kesalihan individual maka kesalihan sosial menjadi semu, sehingga mendiskusikan kesalihan sosial tidak bisa dilepaskan dari kesalihan individual.

Seseorang dikatakan shalih yaitu apabila orang tersebut patuh dalam menjalankan peraturan agama Allah swt, mengikuti apa yang Rasulullah saw contohkan, dan menjauhi apa yang dilarang oleh Allah swt. Pelaksanaan zakat, infaq dan shadaqah sendiri merupakan perintah Allah swt yang disampaikan dalam Al-Qur'an dan dicontohkan oleh Rasulullah saw dalam hadistnya. Maka orang yang membayarkan zakat, infaq dan shadaqah bisa dikatakan termasuk kedalam salah satu ciri-ciri orang yang Shalih. Sebab dengan adanya rasa tanggungjawab terhadap kewajiban serta rasa kepedulian terhadap sesama, hingga mau untuk memberikan sebagian kecil hartanya untuk di zakatkan dan di berikan kepada mereka yang membutuhkan, hal ini menunjukan orang tersebut mencoba untuk patuh terhadap perintah Allah swt dan mengikuti sunnah Rasulullah saw.

Pada dasarnya pengungkapan shalih itu tidak hanya ketika seseorang membayar zakat dikatakan shalih, jika tidak dibarengi oleh amalan shalih lainnya seperti shalat, puasa, dan sebagainya. Akan tetapi ketika seseorang membayarkan ZIS bisa termasuk kedalam golongan yang berakhlakul karimah.

\section{KESIMPULAN}

\section{Simpulan}

Sejarah perkembangan pengelolaan zakat, infaq dan shadaqah masyarakat Rangkasbitung pada tahun 1978-2017 diketahui bahwa sebelum adanya kelembagaan yang mengelola zakat, infaq dan shadaqah secara profesional, dalam pelaksanaannya dilakukan oleh masyarakat Rangkasbitung secara tradisional, dalam perkembangannya kemudian dibentuklah lembaga-lembaga pengelola zakat yang profesional. Dengan adanya kelembagaan pengelola zakat, infaq dan shadaqah maka dalam sistem pengelolaannya lebih optimal dari yang tradisional menjadi lebih modern, dari 
pendistribusian secara konsumtif menjadi lebih produktif.

Nilai sosial yang tercermin dari pelaksanaan zakat, infaq dan shadaqah pada masyarakat Rangkasbitung, secara tradisional para muzakki (pemberi zakat) bisa lebih mengetahui kondisi para mustahik (penerima zakat). Sedangkan secara kelembagaan cenderung hanya menjalankan kewajiban saja.

\section{DAFTAR PUSTAKA}

Abdurrahman, Dudung. (1999). Metode Penelitian Sejarah. Jakarta: Logos Wacana Ilmu.

Al-Ghazali Al-Imam Abu Hamid. 2015. Rahasia Puasa dan Zakat, Mencapai Kesempurnaan Ibadah. Jakarta: PT Mizan Publika.

Arikunto Suharsimi. (2010). Prosedur Penelitian: Suatu Pendekatan Praktik. Jakarta: Rineka Cipta

El Fikri Syahruddin. 2014. Sejarah Ibadah. Jakarta: Republika.

Ghazaly Abdul Rahman, dkk. (2015). Fiqih Muamalat. Jakarta: Prenadamedia Group.

Kartodirdjo Sartono. (1992). Pendekatan Ilmu Sosial dalam Metodologi Sejarah. Jakarta: Gramedia Pustaka.

Kuntowijoyo. (1994). Metodologi Sejarah. Yogyakarta: Tiara Wacana.

Kuntowijoyo. (2003). Metode Sejarah. Edisi kedua. Yogyakarta: Tiara Wacana.

Yafie Ali. (1994). Menggagas Fiqih Sosial. Bandung: Mizan. 